\title{
"In Search of a Lost Eye: The Mythopoetic Dimension in Pedagogy" A Review of Timothy Leonard \& Peter Willis' (Eds.) Pedagogies of the Imagination. Mythopoetic Curriculum in Educational Practice
}

Ragna Aadlandsvik, University of Bergen, Norway

Email: Ragna.Aadlandsvik@iuh.uib.no

\section{Introduction}

Tension has always existed between the two ancient Greek concepts of mythos and logos. Mythos is concerned with the cultural, imaginal, and emotional; logos is related to the rational, pragmatic, and scientific -with what are often called facts. In the West today, it is logos which dominates thinking in all areas, including education. Teachers and educators find themselves in a regime of testing, measuring, standardization, and adherence to prescribed learning outcomes. Schools have become institutions where standard curriculum is delivered and implemented in an almost industrial and commercial way, places where knowledge is transmitted through training, recipes, and routine. In contemporary educational settings, students are often labelled customers. Thus, there has been a gradual change, not only in our way of thinking, but also in our pedagogical practice; teaching seeks to be "cost-effective" and "evidence-based" as a "systematic practice" (Leonard \& Willis, 2009). In many cases, the pursuit of effective academic achievement seems more important than the search for meaning.

I have not, however, given in to absolute pessimism. There are some who speak about broader cultural awareness in education and whose educational practices resist political interference. Editors Timothy Leonard and Peter Willis have compiled articles written by educators from United States, Australia, the United Kingdom, and Canada in Pedagogies of the Imagination: Mythopoetic Curriculum in Educational Practice. In this book, they are not asking us to lead a revolt, but to recognize the inherent value of mythos, and to restore balance between the cultural, imaginal, and emotional (on the one hand) and the rational, pragmatic, scientific (on the other). Having compiled a volume that explores theoretical alternatives to learning theoryincluding socio-cultural theory and narrative theory - the efforts of the editors are a testament to a kind of pedagogical hope. Each contributing author has demonstrated originality in offering the reader alternatives that would help bring logos and mythos back into balance.

In this review, I explain how the collection searches for a figurative "lost eye" as an alternative to Western rationalism. Leonard and Willis characterize the unifying thread of their project as follows: the human intellect is intertwined with the imagination. Thus, in what could 
be summed up as a "mythopoetic project," this collection calls us to resist believing in and relying on what are presented as facts, and instead asks us to turn-or rather, to return-to stories and poetry; to engagement with or in creativity, imagination, aesthetics; and to the involvement of the soul in education.

Mythopoesis, the central concept of the book, is derived from the Greek word for mythmaking (Leonard \& Willis, p. 6). Leonard and Willis' book describes mythopoesis as the process whereby "the reflective imagination is actively evoked and personal and social myths brought forth" (Wright, p. 95) - and these are brought forth generally "in order to generate forms of transformation" (Healy, p. 177). At its best, this myth-making is able to appropriate, retell, and revoice old stories, often with new twists, in ways that allow openings for new meaning to appear. Mythopoesis has relevance for teachers and curriculum workers because they are, to a great extent, contributing to mythmaking. We all live in the stories that make up our lives, including the narratives that constitute our professional lives, and that provide different ways of knowing. In empathy with the collection's focus on mythopoesis, this review draws from an image provided in its second chapter by Holland and Garman. They make reference to an ancient god, Woden, who sacrificed one of his eyes for wisdom. Woden, also referred to as Odin, is the central god in Old Norse (Nordic) mythology. Woden's story, which takes readers back to the roots of my own Norwegian cultural heritage, demonstrates that the stories we live by are not always as local as we sometimes think, as similar stories are evident in many cultures. After losing his eye, Odin was able to drink from a well of wisdom, which was situated under the world tree. Many questions arise from this story: What was gained and what was lost by his actions? Could they have relevance for what we see (and don't see) today? And: Do we today have a kind of one-eyed knowledge resulting from the ascendancy of logos in educational practice?

For human understanding, as well as for educational understanding, we need contributions both from the sciences and from art-the objective and the subjective. Otherwise, as Elliot W. Eisner (1979) states "we are left with a monocular vision; both are necessary to have depth perception" (p. 198). The use of both eyes and the expanded and deepened perception that they together provide is necessary in the complex, evolving enterprise of education. However, like Odin, it seems we in education have sacrificed depth and breadth for a kind of narrow, twodimensional objectivity.

Extending this notion of seeing even further, I would like to remind the reader that the original meaning of theory is to see. A theory is a perspective on the world. Our commitment to logos, to a single perspective, limits our ability to see the rest of the world. The narratives, myths, and poetry of mythopoesis are not to be revived for decorative purposes, but for insight and development. They are forms of knowledge, ways of knowing the world-experiential knowing - that cannot be reduced to other forms without losing what is essential to them, because, as Nussbaum says, "content and form shape one another" (1990, p. 30). Eisner (1992) echoes this thought: "In the arts and in much of life, the form something takes is very much a part of its content. In fact, what the content is often depends on the form it takes" (p. 41).

The editors of Pedagogies of the Imagination are not aiming at a spiritual renewal; rather, they seek to restore the balance between logos and mythopoesis in order to affect broader cultural changes. They make it clear that their approach is a way of synthesizing the best of progressive and critical approaches (Leonard \& Willis, p. 8). Their work does not support an individualistic-educational culture; instead, it embraces an evolving multiplicity of educational practices. The editors remind educators that the spiritual dimensions of human existence must also be taken into consideration pedagogically. It is only a spiritually impoverished people who 
can mistake standardized examinations as the only measures of educational merit and value.

\section{Summary and Discussion: Imagination Against Mindlessness}

In the final sentence of this book, the editors write: "The struggle of imagination against mindlessness must be joined every day” (Leonard \& Willis, p. 266). The message is clear, and it is urgent. It is supported by Eisner, an influential scholar in the educational field who made the claim: "Minds, unlike brains, are not entirely given at birth; minds are also forms of cultural achievement. The kinds of minds we develop are profoundly influenced by the opportunities to learn that the school provides" (2004, p. 8). A school's curriculum is a mind-altering device, a means through which children's minds are shaped in radical and far-reaching ways.

Eisner's position, I believe, is relevant to all kinds of curricula, and in all life stages. We need a cultivation of mind, for all age groups, and in all settings of learning; only then can the potential of mythopoesis be restored and developed. This is not a fancy idea of the moment; rather, it is about a restoration of the imaginal mind as it relates to the core qualities of human life. By making stories, we create meaning, memory, and coherence as individuals and as nations. Stories inform us, and more importantly, they may transform us, allowing us to understand the world in new ways. From a pedagogical viewpoint, it is insufficient to only receive stories; educators must embrace the importance of being authors themselves as they actively draw from and share their experience through stories. A critical aspect, not to be overlooked, is that education must always ask two questions: Whose story is this? Could we cocreate an alternative story?

\section{An Overview}

An overview of the different essays in Pedagogy of the Imagination shows that mythopoesis has relevance in a variety of educational fields. The content is applicable to professionals working in a range of contexts, and with a range of students: in adult education and higher education (Dirx, Willis, Cranton); in child education (Stehlik); in teacher education (Fawns); and in related professions including therapy and counselling (MacKay). There is also relevance to an array of school subjects, including religion (English, Healy), as well as those courses associated with the "factual" - that is, mathematics and science (Leonard). The mythopoetic dimension manifests itself in different modes of expression, not only in stories and explicit narratives, but also in biographies, novels, drama, and theatre (Wright, Doll), as well as in poetry (Mackay, Hilton, Bishop). The mythopoetic's kinship with songs and music is also demonstrated in the collection (Fawns).

A myth has a variety of aspects, among these a moral one (Holland and Garman), and sometimes even a healing one (Bishop). A myth may also have a critical and political aspect. Another facet of myth, or rather, of a mythopoetic pedagogy is its capability to be playful and experimental, or its wild aspect. Davison and Doll, in particular, illuminate the wild characteristics in their respective chapters. A revival for sure, considering more than two hundred years ago, in his "Briefe über die ästhetische Erziheung" (Letters on aesthetic Education), Friedrich Schiller described the revolutionary potential of this urge to play (Spieltrieb). Moreover, a myth may carry its own inherently revolutionary message: things 
should be changed.

\section{Myth, Narrative, Poetry, Imagination}

The titular term mythopoetic is slightly problematic, and may be unclear to many readers. Reference to the mythopoetic is not in common in my own educational discourse, and when used it has some very special and laden undertones requiring some level of discussion. I would have appreciated it if the editors had elaborated and discussed the term more at the beginning, although many of the contributors take up this matter later in the book. In the forward, the term mythopoetic is related to the men's movement and the male psyche which can be a bit confusing, and even disturbing, to a female reader; I really hope that this is a point of historical interest only. This concern, however, does not reduce my profound admiration for, and delight in, the great poet Robert Bly, who to my shameless pride happens to have Norwegian ancestors. I agree with Bly's belief that a fairy tale may contain lessons from the past that are of great importance to modern readers.

Way back in a pagan past, my ancestors may have seen something that has subsequently been forgotten; our modern way of thinking differs greatly from the mythical. We have knowledge, but we tend to place it in isolated boxes. We are good at analyzing, but we may have problems with seeing coherence. Expressed with a modern term, the mythic way of thinking is holistic. Nature is not out there: it is a part of the overall coherence of life and not to be ruled over by humans, as humans are themselves part of nature. Our tendency to separate reason and emotion is likewise unknown in myth. The same applies to the separation between the subjective and the objective, between the cognitive and the affective, between thinking and feeling, between body and mind, and between imagination and reality. My ancestors' history, science, religion, philosophy, and poetry melted into one form: myth. Myth is important in what it does to the listener after the narrative has ended. Myth opens a door, to foster reflection, insight, and understanding of what it means to be a human in the world. It aims to develop a consciousness that life is bigger than the individual.

After having read the book, I have come to see mythopoesis largely as the creation of myths or stories in both oral and written forms. This does not mean that narrative is easily defined or that it is an obvious synonym for a simple story. It is much more than this. In my view, the perspective of this book comes very close to an aesthetic approach; narrative is to a great extent, after all, an aesthetic matter. The two related and important concepts of Greek origin, aesthesis and poiesis, could have been compared in the book. Seen from a certain perspective, poiesis is the more active of the two and, thus, of special pedagogical relevance as demonstrated in this book.

Narrative (from Latin, meaning to know), for the purposes of learning and understanding, represents an activity both on the part of the teller and the receiver of the story. This active participation makes narrative a very potent learning device-so important that some of us are launching an idea of a "narrative learning theory" as a rival to the classic theories of behaviourism, cognitivism, etc. (Aadlandsvik, 2005). The distinction between fictional, or imaginal, stories and real stories is not as clear as one might initially think. All stories are constructed and edited by the narrator; they are not fabricated in some pure sense, but are related to dominant patterns, ideologies, and views. There can be an element of artistry in ordinary people's ordinary stories. Art is not for the few and chosen.

In everyday speech, myth also potentially carries negative meanings. Myth can refer to a 
false conception, a widely held fallacy, a lie, or a misunderstanding. As such, it is often connected to the questions of power, repression, and suppression. For instance, it can be said to be a myth that girls are not good at mathematics. Thus, educators should always be taking on the tasks of critical pedagogy to reveal and deconstruct myths of discrimination and domination. A critical investigation of myths alerts us to their shadow sides, to their negative nuances and overtones, and to their-and also our own-habitual prejudices. Storytellers, too, risk the pitfalls of narrowness and of "one-eyedness."

At first glance, the term mythopoetic wakens thoughts of poetry and the poetic. This book does not explicitly discuss the difference between narrative, which is frequently associated with prose, and poetic forms, which often depart from narrative strictures. To make a distinction between narrative and poetry is a complicated enterprise. In What is Poetry, Jacobson (1933) holds that if we want to say what poetry is, we have to compare it to what it is not; and even that is difficult. In this respect, I am no more enlightened after having read this most inspiring anthology. A good story often has an inherent magic and poetic dimension, but this is not always the case. Poetry is also a way of knowing and a special kind of inquiry (Bishop, p. 107; Hilton, p. 111; Mackay, p. 192), but poetry can also incorporate narrative elements.

Aristotle's explanation in his Poetics is useful in this regard: The poet describes not the thing that has happened, but what is happening and what might happen. This is quite different from an historical account. The poet gives us what Aristotle refers to as a universal event, rather than the concrete details of what "actually" happened. Dewey (1980), perhaps our most influential educational thinker, has often been overlooked as an advocate of art and imagination. The book, Art as Experience, illuminates Dewey's abiding concern with the aesthetic experience and provides a useful distinction between prose and poetry: "One of them [prose] realizes the power of words to express what is in heaven and earth and under the seas by means of extension ... The poetic condenses and abbreviates, thus giving words an energy of expansion that is almost explosive" (p. 241).

In Art as Experience, Dewey (1980) provides a most interesting explanation of Plato's harshness toward poetry and music stemming from the influence these arts had upon the public: The artists were the moral teachers of the people. They were of social and even political significance. Plato's demand for censorship of poetry, for example, was in fact a tribute to this art form. "Words are not exhausted in their power to convey possibility" (Dewey, p. 243). Also, in our time, art is "looked upon with the eye of suspicion by the guardians of custom" (Dewey, 1980/1934, p. 349). Our foremost spokesman of pragmatism here-to the surprise of many academics - shows that aesthetic experience is the most integrated and complete mode of experience in the human quest for meaning. Pedagogies of the Imagination similarly reminds us that poetry is not a lofty thing. Heidegger said that poetry does not fly about and surmount the earth in order to escape and hover over it. Instead, "poetry is what first brings man onto the earth, making him belong to it, and thus brings him into dwelling” (Heidegger as quoted in Leggo, 2005, p. 441; Bishop, p. 42).

Imagination is an important part of John Dewey's philosophical universe. He sees imagination as a vehicle of learning for everybody, the means by which we can bring new realities into existence. Imagination is also the unifying thread of the collection reviewed here. Our ability to understand depends on our ability to imagine - that is, to generate images about the world. There is a basic relationship between mythopoesis and imagination. I agree with the book; it is "the wild, the fantastic imagination that grounds the stories that teachers tell to engage their students" (Leonard, p. 84, emphasis added). Through the "power of evocation the mythopoetic invokes and engages the imagination” (Holland and Garman, p. 21). Imaginal 
knowing is far deeper than fantasy, and it must not be reduced to, or trivialized as, a kind of aesthetic caprice, something belonging simply to childhood or to advertising and entertainment (Bishop, p. 37). This special kind of knowing is linked to the way human beings experience the real world.

The connection between imagination and aesthetics is fairly obvious. When a link between imagination and ethics is considered, the matter becomes far more important and challenging. There could be, in some mysterious way, a certain relation between the moral and the good on the one hand, and art and imagination on the other. "Art ... renders men aware of their union with one another in origin and destiny" (Dewey 1980, p. 271). Finally, we should take notice of the following powerful statement by Dewey: "Imagination is the chief instrument of the good" (ibid., p. 348).

\section{Themes From the Book Chapters}

In Pedagogies of the Imagination, we hear many different voices, most of them with the courage to be personal. In spite of their diversity, what they all have in common is an embodied, mythopoetic dimension combined with, and inspired by, a feeling of discontent with more paradigmatic and conventional approaches in education. All experts in their respective fields, the writers and their particular contributions to the book are discussed individually below, often in a brief and necessarily fragmentary manner. (In comparison to these authors, I am a mere amateur in terms of my own professional background, having been a junior high school teacher, an author of textbooks, a teacher educator, and an initiator of an education program for the elderly.)

Despite the diversity of expertise among the authors, their contributions are bound not only by the mythopoetic and a common resistance to convention, but also by another unifying thread: an interest in poetic language and the narrative nature of learning. Similarly, my research has been inspired by aesthetic theory and phenomenology, as these approaches represent dimensions I find missing in mainstream theory. In opening the book, the editors describe each contribution in a way that both informs and clarifies issues for the reader. They point to the historical roots of their project, showing that mythopoesis is an ancient form of education. Of special importance seems to be the inspiration drawn from the late James MacDonald who, centering his beliefs on the importance of imagination, himself referred to "the curriculum work of ... humanistic and holistic educators mythopoesis” (Leonard \& Willis, p. 2 emphasis added).

\section{Myth is a Way of Knowing}

MacKay reminds us that "etymologically, mythopoesis means the creation of myth or story" (p. 190), and she references Bruner's (1991) influential idea of the two modes of knowing: the paradigmatic and the narrative. The first deals with propositional and scientific thought; the second has to do with the interpretation of experience through narrative.

Davison regrets that over time narrative has ceeded to a paradigm in which cultural stories are giving way to science. People have become observers rather than participants (Davidson, p. 56). But it is also a myth that we have seen the end of myth. In fact, myth has never been stripped from the modern world and there has been a rebirth in the context of counter-cultural movements occurring after World War II. At a time when the practice of teaching has been deformed by a 
move to systemize educational practices, teachers need a mythopoetic capacity. As I've mentioned, there is the tendency to look upon teaching as a kind of production for consumers, as a number of solutions for a finite set of problems-rather than, say, as a "project of emancipation” (Davidson, p. 58). Davison invites students to use a language very different from that of problems and solutions, production, and consumption.

Within both the interpretive and critical paradigms of inquiry, Holland and Garman see myth as a source of knowledge, and the language of poetics as a means of expression that has a particular power, or powers, related to the following: reflection, morality, control, and evocation. Referring to Ernst Cassirer, they call myth "a particular way of seeing” (Holland \& Garman, p. 17). I see a clear parallel in my own work with the elderly and with creative writing (Aadlandsvik, 2007; Aadlandsvik, 2008). It is possible to make a comparison between the poetic and education, and to see them both as emancipatory projects (Synnes et al, 2003). In another book on the importance of narrative in lifelong learning (Aadlandsvik, 2005), I talk about "the turn to narrative." But in fact this is a "return to narrative," as this form of knowing is an old one-apparently as old as humanity itself.

Leonard demonstrates that storytelling and the teaching of mathematics need not be strangers to one another. He relies on the views of Maria Montessori, who also stressed the foundational importance of imagination: "Human consciousness comes into the world as a flaming ball of imagination” (Montessori, as quoted in Leonard, p. 85). Accordingly, Leonard promotes the role of drama and beauty in science education: Let there be light and music in the classroom while the teacher tells the story of the creation of the universe- the Big Bang. The sometimes dramatic life stories of scientists and mathematicians can also be told with the underlying purpose of developing a sense of wonder in students.

Currently in Norway, there is a crisis in science education. Too few students choose this career path. Maybe they have been bored by the abstract, all-too-theoretical, and soulless teaching of the subject, by an experience of the hyper-rational. But nature itself and its study is a matter of wonder; students should be made more aware of nature's miraculous qualities when it is transformed into the subject-matter of school curricula. Stories can represent an alternative in soul-stifling education that is focused on high-stakes assessment. As part of her art-based projects aiming at transformative learning, Cranton used the method of reciprocal storytelling, the exchange of stories among students, and between students and teachers.

I would like to strongly stress the significance of reciprocity in storytelling. Both telling and receiving is important. There is not much point in storytelling when nobody listens. Myths are, above all, stories of transformation. Mackay shows that therapy is also about transformation: “Therapy is about telling, hearing, and retelling stories” (MacKay, p. 194). Hence, as mentioned earlier, it is important that educators become aware of their own stories. In this context, the concept of liminality, of limits, and of their transgression is important. Cranton, working in higher education, says stories "encourage us to think at the edges, at the boundaries" (p. 130). Liminality is especially significant at those points in our lives where the old narratives we tell ourselves, about ourselves, no longer fit, and new narratives have not yet emerged. These liminal spaces are "fructile chaos, a fertile nothingness, a storehouse of possibilities ... a gestation process” (Turner as cited in Mackay, p. 197).

\section{Poetry is a Way of Knowing}

According to Hilton, poetry is a way of knowing, and can also be seen as a form of inquiry that 
pushes boundaries. Poetry "expands and exposes the least accessible areas of experience” (p. 111). Hilton is inspired by poets like Robert Frost and Robert Bly, and he tells a wonderful story of how poetry speaks to us. He also gives us a concrete method for working with poetry in a class setting, one that can produce remarkable results: "We created something in our room that had not been there at the outset," he says (p. 116). I know this feeling very well from my own work with junior high school students and with the aged.

The class is the primary public. The texts they have created, printed and illustrated are handed out for sharing. Knut, a subject in my work suffering from dementia, proudly exclaims: "Did we really make that?" He points to his forehead: "I need something for this one, you see ... This creativity course is like coming home." (Aadlandsvik 2008, p. 332)

Poesis is the expansion of our world even when darkness deepens. MacKay says mythopoetic pedagogy honours the soul, and refers to Siegelman's notion of poetry as the "phenomenology of the soul" (as cited in MacKay, p. 192), rather than of the mind. There is an "original poet in all of us" (Winnicott, as quoted in MacKay, p. 191), a poet who experiences moments of heightened awareness, with "the capacity to see the extraordinary within the ordinary" (p. 191). These words are exactly the same as the ones I utter in my practice, in my writing, and in my life.

\section{Writing is a Way of Understanding}

Writing as embodied learning, as a process of understanding and expressing creativity, is a central idea for Wright. Writing enriches, and in doing so provides something extra. These ideas parallel what I have found in terms of verbal creativity in my work and research related to elderly people. This extra makes you wonder; it paints the sky bluer; it changes your way of seeing things; it opens doors; it strengthens your will to live. This last point was wonderfully illustrated in my workplace when a nurse claimed that Solveig, a 90-year-old participant in my work, would have died weeks earlier than she actually did if it had not been for the writing course she attended. Solveig stated: "I cannot die yet. I have so many stories to tell, and finally somebody listens” (Aadlandsvik, 2007, p. 672-673). This was Solveig's message to a world that she was about to leave. I find this powerful sentiment resonates deeply with Hilton's contribution.

\section{Singing the World, Singing the Profession}

Bishop emphasizes that the mythopoetic is not limited to literary, verbal, or visual forms. Music can also offer important insights (Bishop, p. 45). This seems to be the view of Fawns as well, whose field of expertise is Australian teacher education. Fawns is an advocate of the use of songlines in education. Described prosaically, songlines are cycles of songs that are sung while walking in order to navigate and identify landmarks. In singing, these songs do not just simply correspond to navigational landmarks as they effectively bring them into existence. It is said that in Australia there is hardly a rock or a creek that hasn't been sung in this way. "By singing the world into existence the ancestors," or the Aborigines, Fawns says, have "been poets in the original sense of poiesis, meaning creation” (p. 158). Similarly, the Sami, an indigenous people 
from my own country engage in their own ritual singing. By means of joik, the world is sung: persons, objects, nature, and emotions are brought into being. You don't joik "about somebody," you joik "him or her." The joik expresses and confirms individual identity, which means a great deal among a people for whom the collective is extremely important. It is a way of remembering others; it is a way of reflecting on the world through music, drama, poetry, and narrative, all rolled into one.

Fawns asks his postgraduate students interpret and write about their teaching in terms of the navigation, negotiation, and celebration implied in the songline. Inspired by Martha Nussbaum, Fawns finds that in the "western philosophical tradition, virtue and goodness are collapsed into the rational function of the human mind" (Fawns, p. 159). Meaningful teacher education should be studied in terms of existential practices where the world is sung, he says. As a teacher educator, however, I must admit that parts of this chapter could be clearer to me. They seemed more theoretical than practical. But this musical dimension in teaching and learning appeals to me greatly, and represents a wonderful contrast to the prescribed stages of curriculum delivery central in many teacher-training programs. I look forward to the day when we hear more to counteract the overly functional character of contemporary educational theory -and even to when it might acquire poetic and even musical tones or overtones.

\section{Soul, Spirit, Religion}

Cranton sees that higher education is about to lose its soul, spirit, and heart. According to Dirkx, we need a deeper, more soul-oriented understanding of professional development. Sadly, Schön's theory of reflective practice is insufficient to propel educators into new ways of seeing learning, or to inspire educators to seek a higher meaning. Soul-work is needed, as is inspiration from scholars who stress aesthetic, personal, embodied, and spiritual dimensions. The isolation of faculty life can be dangerous, even toxic, to our spiritual identities in education.

Imagination is an activity of the soul and it "is not we who imagine but we who are imagined” (Hillman, as quoted in Bishop, p. 42). These words sound strange to my Western ears, but I listen when Bishop points to the fact that "all pedagogical organizations have a shadow side,” (p. 48) containing both possibilities and limitations. Between hope and shadow there is a tension, a constant dialectic. Changing the world is not easy, but teachers should try. Bishop discusses the question of reconciliation, an issue not often addressed in educational settings. He wants to break the cycle of revenge, to heal guilt and anxiety, to work for the interrelated processes of acknowledgement and forgiveness, and to show how to engage both hope and transformation. He makes reference to those moments in which the dark, shadow side represented by colonization has dominated. This focus on reconciliation is inspired by the pedagogy of Buddhism and by intellectuals from Africa and Asia. Without doubt, reconciliation is a worthy educational enterprise in a world troubled by multiple legacies of colonial domination.

A significant realization is that educators can meet across the divides of religious dogma in search of deep, common human insights. This possibility is evident in the contribution by Bradbeer and Raheem. Their frame of reference is an Islamic school in Australia, and they assert: "The (true) energy behind schools is the state and the future of the state. In particular, in western democracies, education is about economy" (p. 153). Bradbeer and Raheem argue that despite claims to the opposite, modern schools are not for individuals; rather schooling is a collective enterprise. Accordingly, they advise teachers to affirm the value of learning as an end 
in itself in their practice, and to avoid the enactment of learning as a kind of competition. Students must experience a kind of "travelling to the Mecca of the mind" (p. 140), and see their education as a part of a great journey. The student must come into the temple-the temple of his own heart.

What transpires in our classes is bigger than the system, and our students must always feel this. Despite the rules, the uniforms, the corporate lies, the imperious judgements — and all the things that create fear in the belly for a school student - our classes can become places where the adventure of life opens to its grandeur. (Bradbeer \& Raheem, p. 154)

Leona English, who works in adult education, is inspired by Christian upbringing and theology. She is especially influenced by the Christian mystical tradition in the $13^{\text {th }}$ century, and tells us that her mythopoetic project is a "grail to quest after" (p. 169). For her, mythopoesis is "world spirit, the ground of our being which moves us out into the world of human experience" (p. 170). "To be mythopoetic," she adds, "is to be spiritually grounded" (p. 170). English discusses the relationship between religion and spirituality, and holds that they can be partners. English also speaks about Keats' notion of "negative capability," "a state of receptivity and openness to what might happen" (p. 172). She stresses the importance of building an appreciative research culture and a "climate of safety," a climate in which is it possible "to embrace ambiguity and difference in myself and others” (p. 173). English's students learn to develop professional portfolios and thus to be reflexive about their vocation with a special focus on the positive. The link between the spiritual and the mythopoetic is, in my opinion, not unproblematic. Yet, it has become evident to me in my long teaching career that a focus on a positive, safe, and appreciative learning culture is also crucial in adult education.

Healy questions how the vision of the Jesuit order-with its great importance for education throughout the ages — can be communicated today even as the order is in decline. Healy finds the answer in storytelling. He sees mythopoesis as a kind of pedagogy "where the reflective imagination is actively evoked and personal and social myths brought forth, in order to generate forms of transformation” (p. 177). Healy illustrates his point by using a concrete example. He describes how the life-story of Ignatius Loyola can be brought into relationship with teachers' and staff members' life journeys through the sharing of stories. Healy stresses the transformative potential of this learning and sharing process, and describes its educational effects in a manner that is quite convincing. Yet again, we see that narrative forms offer something that cannot be obtained through more explicitly cognitive modes.

Stehlik writes about the religious undertones found in Rudolf Steiner's Waldorf pedagogyundertones which go some way to explaining the scepticism and suspicion with which this pedagogy is often met. The Waldorf approach is based upon what Steiner called "anthroposophy," which designates a combination of human and "divine wisdom" (Stehlik, p. 232). This philosophy sees child development as occurring in terms of the flowing of a kind of "cosmic stream," (Stehlik, p. 233) in which the child's consciousness retains elements of previous existence. It involves reincarnation, karma and the rhythmic processes of the universe.

In my opinion, ordinary, public schools can draw a lot of inspiration from the aestheticallyinformed approach of Waldorf schools. What I find really sound is the pedagogically-informed avoidance of information technologies, the latter being too heavily and uncritically embraced in contemporary Western schools. 


\section{The Imaginal, the Personal, and the Political}

Prosser shows how a "critical pedagogy that ignores the interpersonal, the imaginal, and the emotional is an insufficient basis for achieving critical aims" (p. 203). He points to the fact that the emotional is not necessarily irrational, and introduces the concept of "critical narrative" (Prosser, p. 205). For Prosser, the mythopoetic involves the hand, the head, and the heart, and he focuses on the increasing importance being ascribed to the role of emotion in the work of teachers. Prosser reports on interviews with teachers who work in areas of socioeconomic challenge. He used stories and personal myths to explain what had inspired their professional development. The mythopoetic emerged naturally from the teachers' accounts. Prosser finds the presence of emotional labor, love, and hope in the teachers' work as they struggled with demands of testing and accountability. Pedagogy is always relational. Love and social consciousness go together. I find Prosser's focus on the political in the context of this special book very valuable. Without this dimension we run the risk of becoming one-eyed, safe, and self-satisfied storytellers -one-eyed in a different but equally problematic way.

Goodson is mentioned in Prosser's chapter as a representative of a critical approach which simultaneously honors aesthetics, imagination, imagery, and myth. Some years ago, I did a series of interviews with Goodson in the United Kingdom and in Norway. At that time, he was already quite worried about international developments in education, and felt that narrow, utilitarian, economically-driven conceptions of curriculum presented a potentially disastrous situation: "It is a ludicrous civilization that would, in the name of economy and efficiency, expel art and sensibility and aesthetics from the curriculum. It is a madness of a particular historical moment” (Goodson, 1999, n.p.).

\section{The Wild, Unpredictable, and Peculiar}

In the concluding chapter, Leonard and Willis stress the importance of alternatives to the domination of linear rationality in education. Rationality needs to be enriched by creative dimensions. In his own chapter, Davison goes a long way in illustrating this point by writing in a very personal tone, and by revealing his belief in the "nonlinear, unpredictable, and wild possibilities in learning" (p. 53). "Productive confusion" in education and learning is his project, which he himself describes as a protest against "pure, unlived reason" (p. 56).

Doll has written the shortest, the strangest, the most obscure-and the most frightening chapter. Her aim is to shake us out of our habitual and civilized thinking and acting, out of our safe orbits. Doll compares capacity to currere, the root of the word "curriculum" that also means "running the course" (p. 229). "Capacity is no friend of accountability, school standards, facts, and competition. Capacity holds room for unknowingness and peculiarity” (p. 223). Doll is a spokeswoman for "unbelievable love affairs" (I leave it to the reader to find out more about such affairs).

Highlighting the numerous possibilities for the concept of capacity in education, she speaks of myth as being above all metaphoric: "offering for those with eyes to see [an access to] the under-layers of human action” (Doll, p. 225). We should see more of what is hidden in the classroom and in academia, learning as Doll says, "to see what knowledge is hiding” (p. 329). If we were to take Doll's warning seriously, a true and necessary revolution in Western schooling would commence. 


\section{Evocation is the Key}

The co-editor Willis believes in phenomenological evocation, and he relates this basic belief to the work of adult educators. Phenomenology is a methodology that aims at presenting lifelike events by creating a vivid portrait of a situation. Willis calls this "imaginal vicarious experience" (p. 248), but uses the word imaginal in a way that is quite different from the meaning of terms like imagination or fantasy. Drama and role-playing are methods for exploring the imaginal, as Willis understands it, and these methods can be said to fit very well with vocational development in education. Drama and role playing, when undertaken with a mythopoetic sensibility, allow students to imagine being in various work situations, and thus gives them a chance to embrace a story that has real-life implications.

In addition to phenomenological evocation, Willis also advocates a specifically evocative pedagogy in career education in the following: "an oblique and non-didactic approach to vocational or career education that seeks to engage the imagination and the heart of the participants" (p. 253). Central to it, he says, is a "dialogic process that uses forms of drama in order to evoke" an emotional and aesthetic "response from [the] imagination" (p. 253). Evocation is a general factor that motivates pedagogy, according to Willis, but perhaps it goes further than that. I once interviewed Eisner (1996) about a possible link between aesthetics and ethics and he responded with hesitation rather than with a quick reply:

Here is something about developing awareness, and here is something about being awake. The big problem for most of us is that we are asleep, and we are not able to wake up. I think a part of art's function is to wake us up. But the fact that you are awake, does that make you more ethical?

Questions like Eisner's do not have simple answers. But the awareness and awakening invoked in the term evocation serve as very good starting point in moral matters. We should notice that anaesthesia is the opposite of aistehesis, the origin of aesthetics - and that both concepts having the same etymological Grecian root. The former puts us to sleep and removes all feelings. The latter alerts us, and evokes and involves our emotions, and makes us see and know in new ways.

\section{Mythopoesis for the Future?}

The editors of Pedagogies of the Imagination ask: Is there a possibility that the ideas of their book can enter mainstream education? They have presented an optimistic and brave answer with their collection. I would also like to take the opportunity to mention an important parallel. For many years Eisner's ideas were marginalized, but over the years they have proved vigorous and are now of much greater importance than they were in previous decades. To move forward, we will need very strong winds and bravery; the voyage could prove rough, as "we need to sail against the tide" (Eisner, 2004, p. 10).

I think in most cases, the risk of ignoring and silencing is bigger than the risk of resistance in academia. Silence is a powerful tool in maintaining the dominant viewpoint. Silence may also signify a lack of good and qualified arguments. Or it is perhaps a paranoid silence that simply has more to do with the suspicious nature of guardians of custom (a concern Dewey alludes to above)? In a few cases, we may hear about the seductive power of an aesthetic approach. Far 
more powerful, however, may be the seductive power of statistics and the "hard data and stiff methods" valourized in the standardized measures that have come to define educational practice.

Regardless, it is a fact that the idea of using both eyes has begun to surface in professions other than education. This is illustrated in the normally logos-oriented medical profession; this profession's use of narrative sources has increased greatly in recent years. This corresponds to the recognition that "literature is vital in medicine and health care, providing knowledge and offering crucial understandings of the narrative nature of human lives ... illness is seen from the patients perspectives and we can be moved by what we hear'’ (Kaptein \& Lyons, 2009, p. 162).

\section{Mythopoesis and Phenomenology}

What makes a book of this kind interesting in a phenomenological context? There are many parallels between mythopoesis and phenomenology:

Phenomenology, not unlike poetry, is a poetizing project; it tries an encantive, evocative speaking, a primal telling, wherein we aim to involve the voice in an original singing of the world ... it is a language that reverberates the world, a language that sings the world. (Merleau-Ponty as quoted in van Manen, 1994, p. 13)

It would be a natural connection for the reader to associate this quote with the songlines of the Aborigines discussed by Fawns, and with my own invocation of the joik of the Samis people. This "primal incantation or poetizing which harkens back to the silence from which the words emanate” (van Manen, 1994, p. 13) has its parallel in the way the myth-inspired Orcadian poet, George McKay Brown (1977), expresses it in the poem, The Poet. The true task of the poet's stare, McKay Brown says, is the "interrogation of silence" (p. 37). A phenomenologist aims to return to the phenomena themselves by means of "phenomenological reduction," and at letting the things speak "just as we experience and encounter them: see, feel, hear, touch and sense them” (van Manen 2001, p. 4). Whether through song or resonant silence, things become real through voice and hearing. This is very similar to what a poet does. In poetry, the world is encountered afresh and created anew.

Phenomenology has an affinity with aesthetics. Van Manen finds that "aesthetic sources may assist in presenting a range of experiential material that shows the variety, richness, and subtleties of lived meaning in human life" (van Manen, 2001, p. 6). A phenomenological text is vocative; it speaks to us, we are then responsive; it also evokes a sense of wonder, a questioning of the taken-for-granted aspects of life. Phenomenology not only finds its starting point in wonder, it must also ends in wonder; and as van Manen reminds us of the following: "The opposite of wonder is matter of factness” (2005, p. 251).

Phenomenology slows us down, says Willis (p. 249). It is something substantially different from our activist search for results and findings, so willingly supported by contemporary scholarly priorities and discourses. Moreover, phenomenology normally has a moral dimension, with a focus on the uniqueness of the other person, on each person's essential dignity. Similarly, stories can make us see and feel profoundly with the other, imagining a world larger than the one we inhabit: "Narrative allows us to enter empathically into another's life and being-to join a living conversation. In this sense it serves as a means of inclusion, inviting the reader, listener, writer or teller as a companion on another’s journey” (Witherell, 1995, pp. 40-41). 
A special form of narrative and perhaps also of myth is represented by the anecdote, commonly used in hermeneutic-phenomenological texts, where they are employed as a rhetorical and methodological device (van Manen, 1994). The anecdote aims at expressing or capturing aspects of an experience, and at providing for hermeneutic-phenomenological analysis the multiple layers of meaning that a particular experience provides. Anecdotal accounts are a special kind of story, and van Manen invokes the Aristotelian definition of poetry and history in explaining how the anecdote integrates both of these modalities. "The paradoxical thing about anecdotal narrative is that it tells something particular while really addressing the general and the universal” (van Manen, 1994, p. 120; emphases added). As van Manen says, writing exercises our ability to understand that "we are what we can see” (p. 130).

"Anecdotal” writing is not always appreciated in academia. In the eyes of the critics, it may appear childish and unscholarly. Such criticisms could be dismissed, but they also contain a grain of truth. To write truly, poetically, to sing the world, is a demanding task, and not everyone who tries succeeds. Sometimes in phenomenological writing the magic of the poetic dimension is lacking. Such writing requires education, practice, and critique.

The phenomenological project is a writing project. By developing or entering spaces of texts, one aims at reflection and understanding in which the "writer dwells in the space that the words open up" (van Manen, 2005, p. 2). How joyful this dwelling can be for the maker, and for the receiver! In much of conventional educational research, the element of joy is strikingly absent. One can almost hear the dry rustling of a language that is colourless and lifeless. Barthes (1986) expresses this as follows: "Last, between science and writing, there is a third margin, which science must reconquer: that of pleasure” (p. 9). It is my firm belief that poetic language, with its physical nature, can contribute to such pleasure.

\section{Imagination is Liberation}

A "pedagogy of the imagination," living with what is possible in the moment, is also a pedagogy of liberation. It is democratic in the sense that it supports different dispositions and abilities. Imagination plays an important role in the construction of different worlds. And it supports inner freedom, the most precious freedom of all, not the least in times of distress.

This book stands in opposition to a kind of learning that has narrow and instrumental purposes, and it advocates learning of a more existential kind. How can we measure solidarity, kindness, and forgiveness? Or compare persons and their capacities - things that are marked, above all, by their originality and uniqueness? At the moment, issues of schooling that are much more trivial get much more attention. Learning for life should be of equal importance to learning for a living. Today, there is a dramatic gap between what is measured and what really matters. Schools and universities should become places where the journey of life is evident in all its grandeur. "What transpires in our classes is bigger than the system" (Bradbeer \& Raheem, p. 154). We must learn to see what the positive knowledge of measures and testing is hiding (Doll).

\section{Final words}

"What we call the beginning is often the end/And to make an end is to make a beginning" says T. S. Eliot in the poem Little Gidding (Roberts, 1965, p. 113). The basic ideas of Pedagogies of the 
Imagination have deep cultural roots, and the task of each new generation of educators is to protect and advance the kinds of visions invoked by this book's central ideas. Ideas of the kind can illuminate our professional lives, and can even provide the impetus for the initiation of a genuine pedagogical renewal. The poetic means that, rather than being simply repeated, stories must be re-told for the sake of new generations, and also to generate new meanings.

I find this book of tremendous importance and relevance, not as a song sung as a solo, or as a voice crying in the wilderness, but as educators united in the imaginal. Other books on similar themes have appeared, and in this sense Pedagogies of the Imagination adds to a growing chorus expressing discontent and giving voice to alternatives. Together, with these other books, Pedagogies of the Imagination makes a genuine contribution by filling a gap in contemporary educational discourse by asking educators, in a pointed and compelling way, whether they have traded an eye-and the perception of depth and breadth it would bring-for the narrow "wisdom" of evidence-based practice and testable knowledge? This book echoes, more than any book I have read in recent years, my own ideas and experiences. I feel a strong kinship, perhaps more related to the heart than intellect, with these authors from different corners of the world.

Educators must neither be blinded nor one-eyed when it comes the fact that the world is still a place of radical materialism and social injustice, and that serious pedagogical debates are for many people a luxury. Myth cannot replace money at a time of economic disaster. Nor can it simply solve threatening environmental problems. However, a social-material transformation, can, as Pinar points out in the foreword, occur through spiritual renewal. Myth will always be connected to the source or the deep well of true wisdom, called "the well of Mime" in Norse mythology. Wandering in the figurative desert of positivist and commercial discourses, we are in danger of losing our way-and our ability to return to this ancient and life-giving source. We need images and visions of a better world and another social order. We must learn to see what knowledge is hiding.

\section{References}

Aadlandsvik, R. (2008). The second sight. Learning about and with dementia by means of poetry. Dementia, 7(3), 321-339.

Aadlandsvik, R. (2007). Education, poetry and the process of growing old. Educational Gerontology, 33, 665-678.

Aadlandsvik, R. (Ed.). (2005). Læring gjennom livsløpet (Learning through the life span). Oslo: Universitetsforlaget.

Barthes, R. (1986). The rustle of language (R. Howard, Trans.). Los Angeles: University of California Press.

Brown, G.M. (1977). Selected poems. London: The Hogarth Press.

Bruner, J.S. (1991). The narrative construction of reality. Critical Inquiry, 18(1), 1-21.

Dewey, J. (1980). Art as experience. New York: Perige Books. 
Eisner, E.W. (2004). What can education learn from the arts about the practice of education? International Journal of Education \& the Arts, 5(4), 1-12.

Eisner, E. W. (1996). Interview with Ragna Aadlandsvik at Stanford University, Stanford CA.

Eisner, E.W. (1994). Cognition and curriculum reconsidered (2nd Ed.). New York: Teachers College.

Eisner, E.W. (1992). The misunderstood role of the arts in human development. Phi Delta Kappan, 73 (8), 591-95.

Eisner, E.W. (1979). The educational imagination. On the design and evaluation of school programs. New York: Macmillan

Goodson, I. (1999). Interview with Ragna Aadlandsvik at University of Bergen, Norway.

Hillman, J. (1985). Archetypal psychology: a brief account. Dallas: Spring.

Kaptain, A.A., \& Lyons, A.C. (2009). The doctor. The breath and Thomas Bernhard. Using novels in health psychology. Journal of Health Psychology, 14(2), 161-170.

Leggo, C. (2005). The heart of pedagogy: On poetic knowing and living. Teachers and teaching: theory and practice, 11(5), 439-455.

Nussbaum, M. (1990). Love’s knowledge. Essays on philosophy and literature. Oxford: Oxford University Press.

Roberts, M. (Ed.). (1965). The Faber book of modern verse (3rd Ed.). London: Faber and Faber.

Synnes, O., Saetre, O.G., Aadlandsvik, R. (2003). Tonen og glaset. Pedagogisk arbeid med eldre og verbal kreativitet (The tone and the glass: Pedagogical work with elderly people and verbal creativity). Kristiansand: Høyskoleforlaget

Van Manen, M. (Ed). (2005). Writing in the dark. Phenomenological studies in interpretive inquiry. London, Ontario: The Althouse Press.

Van Manen, M. (2001). Professional practice and ‘doing phenomenology’. Handbook of phenomenology and medicine (pp. 457-474). Dordrecht: Kluwer Press.

Van Manen, M. (1994). Researching lived experience. Human science for an action sensitive pedagogy. London, Ontario: The Althouse Press.

Witherell, C.S. (1995). Narrative landscapes and the moral imagination. Taking the story to heart. In H. McEwan \& K. Egan (Eds.), Narrative in teaching, learning and research. New York: Teachers College Press. 
Ragna Aadlandsvik 110

\section{Appendix}

Contributors to Pedagogies of the imagination: Mythopoetic curriculum in educational practice

Foreword by William F. Pinar

1. Introduction. Timothy Leonard and Peter Willis.

Part I Mythopoesis and Curriculum Theorizing

2. Watching with two eyes: The place of the mythopoetic in curriculum inquiry. Patricia E. Holland and Noreen B. Garman.

3. The shadow of hope: Reconciliation and imaginal pedagogies. Peter Bishop.

4. Myth in the practice of reason: The production of education and productive confusion. Aidan Davison.

5. Care of the self: Mythopoetic dimensions of professional preparation and development. John M. Dirkx.

6. Imagination and mythopoesis in the science curriculum. Timothy Leonard.

7. The mythopoetic body: Learning through creativity. David Wright.

8. Autobiography and poetry. Peter Hilton.

9. The resilience of soul. Patricia Cranton.

Part II Mythopoesis in Educational Practice

10. Imaginal transformation and schooling. James Bradbeer and Abdul Ghafoor Abdul Raheem.

11. Idealism and materialism in the culture of teacher education: The mythopoetic significance of things. Rod Fawns.

12. Spiritual grounding and adult education. Leona M. English.

13. Ignatian spirituality as mythopoesis. Gerry Healy.

14. Mythopoetic spaces in the (trans)formation of counselors and therapists. Frances MacKay.

15. Critical pedagogy and the mythopoetic: A case study from Adelaide's northern urban fringe. Brenton Prosser.

16. Capacity and Currere. Mary Doll.

17. Thinking, feeling and willing: How Waldorf schools provide a creative pedagogy that nurtures and develops imagination. Tom Stehlik.

18. Getting a feel for the work: Mythopoetic pedagogy for adult educators through phenomenological evocation. Peter Willis.

19. Conclusion: The mythopoetic challenge. Timothy Leonard and Peter Willis. 